\title{
Sampling Plan to Support HLW Tank 16
}

by

P. O. Rodwell

Bechtel

Savannah River Site

Aiken, South Carolina 29808

B. Martin

This paper was prepared in connection with work done under the above contract number with the U.S.

Department of Energy. By acceptance of this paper, the publisher and/or recipient acknowledges the U.S. Government's right to retain a nonexclusive, royalty-free license in and to any copyright covering this paper, along with the right to reproduce and to authorize others to reproduce all or part of the copyrighted paper. 


\section{DISCLAIMER}

Portions of this document may be illegible electronic image products. Images are produced from the best available original document. 
WESTINGHOUSE SAVANNAH RIVER COMPANY HLW ENVIRONMENTAL ENGINEERING
WSRC-TR-97-00350

REVISION: 0

TRACK\# 10048

KEYWORDS:

TANK 16, TANK

CLOSURE, WASTE

REMOVAL

RETENTION:

PERMANENT

DISPOSAL AUTH.

DOE 1-9.A

HLWM Information

No Classification or UCNI

Required

\section{SAMPLING PLAN TO SUPPORT HLW TANK 16}

OCTOBER $30,1997$.

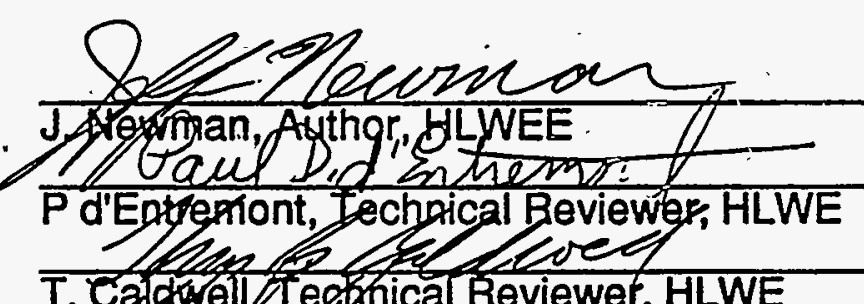

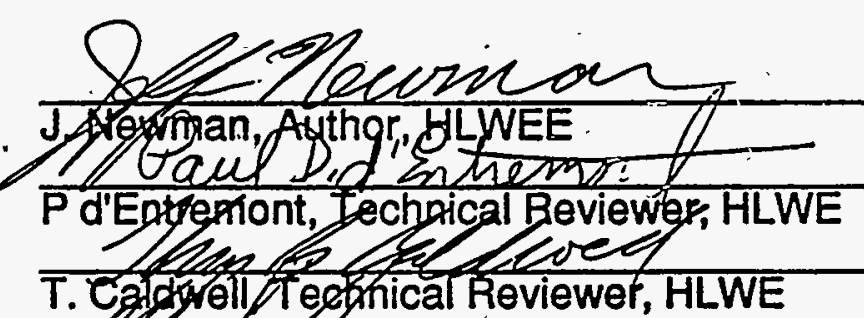

Date:

MTlay, Teffricas Reviewer, SRTC

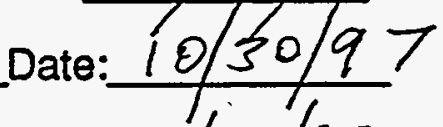

Date: $10 / 30 / 97$

Date: $10 \% 30 / 97$ 


\section{INTRODUCTION AND SUMMARY}

Plans are to remove the residual waste from the annulus of High Level Waste Tank 16, located in the H-Area Tank Farm, in 1998. The interior of the tank is virtually clean. In the late 1970's, the waste was removed from the interior of the tank by several campaigns of waste removal with slurry pumps, spray washing, and oxalic acid cleaning. The annulus of the tank at one time had several thousand gallons of waste salt, which had leaked from the tank interior.: Some of this salt was removed by adding water to the annulus and circulating, but much of the salt remains in the annulus.

In order to confirm the source term used for fate and transport modeling, samples of the tank interior and annulus will be obtained and analyzed. If the results of the analyses indicate that the data used for the initial modeling is bounding then no changes will be made to the model. However, if the results indicate that the source term is higher than that assumed in the initial modeling, thus not bounding, additional modeling will be performed.

\section{PURPOSE AND DISCUSSION}

The purpose of this Plan is to outline the approach to sampling the annulus and interior of Tank 16 as a prerequisite to salt removal in the annulus and closure of the entire tank system. The sampling and analysis of this tank system must be robust to reasonably ensure the actual tank residual is within the bounds of analysis error.

Process knowledge of the residual concentration in this tank system is sufficient to enable groundwater fate and transport modeling to proceed. If analysis results indicate certain radionuclides are present in concentrations greater than predicted, then the process knowledge inputs to the modeling will be adjusted accordingly.

Only one sample of the tank primary is required. No attempt is required to conduct a representative sampling regime of the tank interior. The tank interior was agitated extensively during bulk waste removal, spray washing, and oxalic acid cleaning, so the material left behind should be relatively homogeneous.

Three samples are planned from the annulus. The waste solution that leaked from the Tank 16 primary into the annulus leaked during a short period of time (about a year), so the waste was relatively homogenous. However, if some sludge leaked into the annulus with the salt solution, the sludge would have settled to the bottom of the annulus pan. Therefore, it is important that one of the samples from the annulus be collected by scraping the bottom of the annulus pan to ensure that any sludge residues that might be present are sampled.

Modeling results will be obtained for sludge waste and for supernate waste from process knowledge estimates. This will provide boundaries for the expected values of the actual sample characterization modeling.

Two companion reports will be produced to augment this Report. The Waste Characterization Report for Tank 16, issued by HLWE, describes sludge and supernate radionuclide and hazardous constituents remaining in the annulus and tank interior. The Characterization Plan for Tank 16 Samples, issued by SRTC, 
describes the preparation of the samples and the specific analysis to be conducted on each prepared sample.

\section{APPROACH}

The salt remaining in the annulus space of Tank 16 ranges between 0 and 12 inches high. Salt also remains in the ventilation duct work in the bottom of the annulus space. This salt residue is what remains from salt that escaped from the main tank interior through leak sites. It is not believed that any sludge escaped the main tank interior into the annulus space.

Based on past photography experience, unobstructed access to the tank 16 annulus can be obtained at inspection Port (IP)35, IP118, IP207, IP262, and the east and west risers. IPs have $6^{\prime \prime}$ dia. Riser ports have $5^{n}$ dia. (Annulus risers have $30^{\prime \prime}$ dia.)

Three $100 \mathrm{ml}$ annulus samples are planned for. However, the minimum quantity of sample material from the combined three annulus samples must be $200 \mathrm{mls}$ or greater, in order to complete subsequent dissolution testing. These three samples are to be taken from different areas around the circumference of the annulus. Specific locations were designated as IP35 (or vicinity), IP118, and east riser. These locations were chosen because of the level of salt buildup in these areas. A sample is to be scraped off the annulus floor where there is a low level of salt buildup in the vicinity of IP35. As mentioned previously, if any sludge leaked into the annulus, it should be found in this scraped sample. Samples will be taken from the high level of salt buildup at IP118 and middle level of salt buildup at the east riser. The samples from IP118 and east riser may be obtained by the most expedient method allowable (i.e.. scraping, breaking, coring', etc. is acceptable.)

A sample scraped from the tank 16 interior tank floor residual material is required for closure characterization. The "scraping sample tool" should be designed to take this sample as well as the annulus samples. The tank interior floor sample can be obtained anywhere along the tank bottom. Therefore 4 initial samples will be required - 3 annulus samples and 1 tank interior bottom sample.

An intact core sample. will not be required. Because the waste leaked from Tank . 16 in a short period of time, the composition of the salt is expected to be relatively uniform. Samples taken as described above are expected to provide sufficient closure characterization data. A sample from the annulus duct will not be required initially.

There is, however, enough uncertainty associated with the contents of the tank 16 annulus, that additional samples may be required. Additional samples will be required if -

1) there is significant inconsistent data from the three initial annulus samples, or

2) the performance evaluation modeling from the actual sample characterization does not fall within the process knowledge analysis boundaries for supernate and sludge as described in g) above. 


\section{SAMPLE CHARACTERIZATION}

Samples taken from the Tank 16 system will be analyzed by SRTC, in accordance with the Characterization Plan for Tank 16 Samples. The samples will be received and prepared for analyses in the SRTC Shielded Cells Facility using normal handling procedures. Radiation rates for the samples are expected to be significant, in the $\mathrm{R} / \mathrm{hr}$. range. Once the samples are prepared for analysis they will be transported to the analytical laboratories where they will be characterized by the Analytical Development Section of SRTC using standard. analytical procedures.

\section{SCHEDULE}

An aggressive sample schedule is proposed to support a salt removal demonstration in tank 16 annulus in FY98. Planning schedule milestones include:

12/1/97 - Obtain 4 initial samples ( 3 annulus, 1 tank interior bottom)

1/15/98 - Complete lab analysis and characterization.

2/2/98 - Complete performance evaluation modeling, using the MEPAS model used for Tanks 20 and 17 or equivalent, and decide if additional tank 16 annulus cleaning is required.

- Complete dissolution lab testing of the tank 1.6 annulus sample material. This will provide input to the technology application decision for tank 16 annulus cleaning demonstration. 